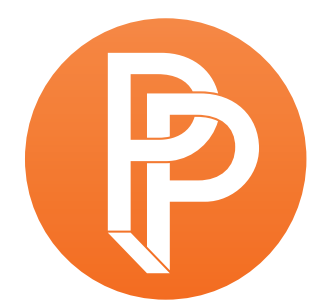

PERFORMANCE

PHILOSOPHY

\title{
PINE-ING FOR A VOICE: VEGETALAGENCIES, NEW MATERIALISM AND STATE CONTROL THROUGH THE WOLLEMI PINE
}

\section{CHANTELLE MITCHELL AND JAXON WATERHOUSE INDEPENDENT SCHOLARS}

At some point in our lives, most of us will engage in some way with a language of flowers; their use to convey a sentiment beyond mere words. This may be a bouquet of roses given to a loved one, for example, or of lilies upon the occasion of a death. The exchange of floral arrangements is a performative and linguistic signal, for embedded within these bouquets are coded gestures; emotion conveyed by and through petals and leaves. Whilst the concept of a language of flowers exploded in popularity in the West in the nineteenth century, it is suggested that the employ of flowers 'as meaningful signs that are claimed in the service of science and sentimentality' can be traced back through history (Kranz 2017, 195).

This language of flowers is 'based on the idea that one can communicate feelings by encoding them in floral signs,' a vernacular language tied to place, but too, to the Earth from which the flowers bloom forth (194). The floral, laden with symbolic meaning, becomes a linguistic tool wielded by the human. But when we consider the sheer immensity of plant matter, which comprises some $80 \%$ of the Earth's biomass, we ask what of those other plants, those which would never be included in a bouquet? What could it mean to divine a language for those plants? What meaning have they accrued, and how have they been co-opted as a tool towards human ends, beyond their immediate practical uses of food, fuel and shelter? Through this paper, we attend to the Wollemi Pine (Wollemia nobilis), considering what this plant might convey in the form of a vegetal shorthand and to what ends this is mobilised; but further, what it might mean to read this plant, and listen to it from a New Materialist perspective. In introducing this paper with the concept of a language of 
flowers, we take a step towards a vegetal communication. While our engagement here is with the Wollemi as species, rather than its gymnosperms, there is a recognisability in this concept that proves an entry point from which we can further excavate human and plant communication within theoretical frames. The Wollemi, a monumental and prehistoric tree growing in secret seclusion in the Blue Mountains of New South Wales, on the lands of the Wiradjuri, Dharug, Wanaruah and Darkinjung people; presents a unique case study through which to consider vegetal agency amidst communication, contemporary geopolitics, and the so-called Anthropocene.

In his considerations of plant intelligence, Daniel Chamovitz acknowledges that 'Plants lack the structures for purposeful vocalization' $(2012,17)$. Beyond vocalization, the communication of plants is identifiable through movement and chemical signalling, a fact spoken to by theorist Michael Marder (2013a, 75). Yet, the notion of a language of flowers imposed upon the vegetal belies the 'uniqueness of [plant] existence,' limiting the possibilities of vegetal communication to narrow anthropocentric modes of communication (Marder 2013a, 8). However, through New Materialist frames which recognise the agentic force of the more-than-human, it becomes possible to apprehend plants as active and willful, but also part of a co-constitutive network of relations. Broadly, New Materialism can be understood as the embrace of 'a non-anthropocentric realism grounded in a shift from epistemology to ontology and the recognition of matter's intrinsic activity' (Gamble, Hanan and Nail 2019, 118). Within this, however, we focus upon a vital New Materialism, one heralded by the 'ontologization of an immanent activity of vital forces minus the mechanistic passivity of atomic matter' (Gamble 2019, 120). These new (or renewed materialisms) allow for comprehensions of agency alongside developments and shifts in the natural sciences which, as we will encounter through the vegetal, allow for transformations in traditional hierarchies of value across the human and the more-than-human (Coole and Frost 2010, 2).

While this theoretical framework remains troubled, thinking in this manner provides a grounding from which to re-evaluate the significance of matter; wherein it is possible to apprehend the 'certain vital force' inherent in agents prior to this force being enacted through any kind of performative relationship (Bennett 2010, 24). The vegetal provides a ready example with which we can mobilise this mode of thinking, in consideration of the molecular level at which plants operate. As Natasha Myers explains in light of the photosynthetic processes undertaken by plants, 'pulling matter out of thin air, [plants] teach us the most nuanced lessons about mattering and what really matters: their beings and doing have enormous planetary consequences' (Myers 2016). Reconsidering matter through New Materialism offers an insight into the manner in which the more-than-human has been constructed, shaped and limited through the primacy placed upon the worldmaking capacities of the human, and the anthropocentric veil placed over all else. The reevaluation of the more-than-human that occurs within New Materialism affords an opportunity to begin again; starting with the base matter that comprises beings, from which we can apprehend the vital force inherent within their physical structures and perceive them as agentic beings. In reevaluating the position of plants and recognising plant agency beyond the human, it becomes possible to think of relational entanglements in which plants too have 'histories, forged in ongoing relations with surroundings that may or may not include human beings' (Ingold 2011, 31). Attuning to these histories (but also their presents and futures) in relation to a vegetal communication 
requires 'Listening for the response of the other and an obligation to be responsive to the other, who is not entirely separate from what we call the self,' or recognition of the co-constitutive nature of being-in-the-world (Barad 2012, 69). This occurs in contrast to the ascription of symbolic meaning to the vegetal, as identified in the language of flowers mentioned earlier-a one-way communication of talking for, not talking with the vegetal.

Exploring the communicative capacities of these plants and the manner in which they are spoken over by the human unfurls complex entanglements of power and place, highlighting the continued imposition of a muteness upon the vegetal. It is 'plant blindness;' a resultant tendency to either ignore, discount or speak over the vegetal, offers Jeffrey Nealon, in tracing a line of philosophic thought through Heidegger and Aquinas back to Plato, that ensures that plants remain in the position of 'the lowest threshold of living things: stuff that lives solely to serve the other, "higher" beings' $(2015,30) .{ }^{1}$ This narrowing of vegetal existence by Plato to mere food for the human seeded the figuration of plants as ontologically static and mute, absent of 'world' in any meaningful sense. Contemporary philosophical and scientific approaches, however, move beyond these limited framings, recognising and emphasising the motion, agency and willfulness of the vegetal realm, and it is within this expanded frame that our examination of the Wollemi Pine takes place. Indeed, by listening to, or becoming aware of the communicative capacities of plants, we are presented with an opportunity to destabilise traditional Western philosophical framings of humannature hierarchical relationships, and to move towards a recognition of plants as kin-which holds enormous potential for constructive mobilisation and change in the face of our unfolding climate crisis.

\section{Landscapes of Vegetal Agency}

Amidst the destabilisations of this crisis, Myers offers a helpful shift away from the anthropocentric notion of the Anthropocene, an acknowledgement of the crucial role of the plant world in supporting life on Earth through what she has termed the 'Planthropocene.' She writes that, 'we are only alive because they are. The thickness of this relation teaches us the full meaning of the word interimplication' (2017, 125, italics added). This interimplication is our entanglement with the plant word, the undeniable connection between the human and vegetal. Recognising this entanglement, and our dependency upon the vegetal it implies, Myers further offers, is a crucial step towards 'vegetalizing our human sensorium' (Myers 2014), in order to 'make allies with these green beings' and 'get to know them intimately and on their terms' (Myers 2016). In the words of Hannah Pitt, plant knowing is plant being, and by building practices of reciprocity, rather than paternalism in relation to plants, it becomes possible to enact plant-human relationships that apprehend the agency of the vegetal (Pitt 2016).

Bawaka Country et. al. presents a unique example of listening to, learning from and collaborating with plants as agentic through the experience, practice and publication of research into ways of reciprocal being (2015). This collaborative research project involves many voices and emerges from the knowledge of the Gumatj people. Uniquely, however, Bawaka Country, the land itself, is acknowledged as contributor and collaborator, given voice within research through attunement, 
connectivity, and recognition of being beyond anthropocentric frames. Whilst this text does not proffer to achieve the collaboration, consultation and shared plant knowledge as undertaken by Bawaka Country et. al., the possibility of knowing plants upon their own terms presents an opportunity to listen in recognition of plant agency

We perceive the recognition of plant agency as a key tenet of 'collaborative survival,' as outlined by anthropologist Anna Tsing; survival only possible through a reconfiguration and strengthening of kinship ties in human/more-than-human relationships $(2015,20)$. Contemporary approaches to the more-than-human have sought to challenge framings of matter which subordinate the agency and presence of animals, plants, geology and beyond in service of this aim. These New Materialist and posthumanist approaches recognise the formerly 'ghost-like presence in contemporary theoretical approaches' of plants (Jones and Cloke 2002,4), refuting the inertness ascribed to nature in the face of human action (Gibson 2018, 5), and arguing for greater recognition of vegetal being amidst the broader shift toward ecological agency within theory. In challenging these framings and seeking to render apparent the thick interimplication of the human and vegetal, emergent landscapes of vegetal ecologies counter the denigration of plant life as immobile and non-sentient. A multitude of perspectives contribute to such thinking, with plants positioned as 'entangled in political, economic, and cultural systems' (Kirksey et al. 2014, 1), an approach furthered by multispecies ethnographies (Kirksey and Helmreich 2010; Tsing 2015), and decolonial approaches (Bousfield 2020; Mamdani 2012). Further, New Materialist approaches (see Bennett 2010, 8; Braidotti 2019) and agentic approaches (Marder 2013b; Tsing 2012)² reinforce that 'nature can no longer be seen as an inert backdrop to human action' (Gibson 2018, 5).

Challenging the positioning of plants as 'the furniture of the planet, necessary, useful, attractive, but "just there'"' (Mabey 2016,4) requires a change in human perception of plants. Marder writes, in seeking to illuminate the agentic actualities of plant life beyond the human frame: 'the performativity of plants is their mode of being in the world-their affecting and being affected by the places of their growth. Plants are artists of themselves: they create themselves and their environments all the time' $(2018,26)$. For Tsing, in reference to the work done by Marder in this area, 'The idea that plants should be an icon of stillness, rootedness and passivity is an unfortunate legacy of Western philosophy's neglect of actually existing plants' (Tsing 2017, 21; see also Marder 2013). Plants engage in their own rich lives of movement and transit. From vertical growth which sees canopies grow tall, to roots burrowing into the earth, holding together soil and cultivating mycorrhizal relationships, to migratory journeys of growth, the movement of plants enables rich vegetal ecologies across place. These vegetal ecologies are spaces of engagement, collaboration and communication.

The conception of vegetal ecologies as spaces of symbiotic living and interaction is buttressed by the recognition of plants as possessing 'active intelligence' (Trewavas 2002; Hall 2011, 144), a foundational aspect of which is their capacity to communicate and interact both above and below ground. Above ground communication may occur during reproduction, or amidst plant-herbivore relationships, through the deployment of certain scented chemicals to attract pollinators, for example (Hall 2011, 153). In terms of subterranean communication and interaction, this can take 
place through allelopathy, which is the secretion of secondary metabolites from root systems so as to suppress the growth of neighbouring plants (152). Studies also demonstrate the capacity for the roots of various plants to 'veer away from competition with the roots of other species' (153). Recent studies also demonstrate the manner in which plants can act as 'green phones,' mediating communication between above-ground and below-ground insect life (Soler et al. 2008; Pangesti et al. 2013). Indeed, it is the case that '[p]lants move, they move other things, they move people, and they are themselves being moved around' (Thorsen 2017, 11). These vegetal ecologies are rich and deep entanglements, like the subterranean morass of mycorrhizal interactions that occur out of sight. It is the case also, however, that humans are deeply enmeshed within these vegetal ecologies, with or without us realising it-although within the Anthropocene, it is becoming increasingly hard to ignore.

As this perception of the vegetal world as static changes, we are increasingly exposed to the artificiality of the privileging of human over nature; a construct accepted as truth only through its durational and persistent presence. Time is a significant aspect to the encounter between the human and vegetal, and the development of vegetal ecologies. We think here of the length of the relationship between the human and vegetal. As Bruno Latour acknowledges, human history and communication is tied up in the vegetal: 'We cannot disentangle our bodies, our houses, our memories, our tools, and our myths from their knots, their bark, and their growth rings. You hesitate because I allow this tree to speak? But our language is leafy and we all move from the opera to the grave on planks and in boxes' $(1993,95)$. But we also apprehend the dissonance that exists within this encounter; the 'time-lag between the human and the plant: the wildly different time scales of movements, behaviors or responses,' as identified by Marder $(2018,28)$. Within this encounter, taking place across temporal and ontological zones, there is a possibility of dismantling the framing of plants as the 'lowest threshold of living things' $(2015,30)$, toward 'contingent, embodied and less linear human-plant histories,' which seek to recognise the co-constitutive powers of the vegetal world (Head and Atchison 2009, 241; see also: Doolittle 2004; Farley 2007; Jones 2007). Within a New Materialist context, we acknowledge that 'phenomena are caught in a multitude of interlocking systems and forces and [...] consider anew the location and nature of capacities for agency' (Coole and Frost 2010, 9).

Indeed, what might emerge from such capacities, and what would a shared history look like? The existence of the Wollemi stretches back some 200 million years, far eclipsing the lifetimes of humanity's earliest ancestors. How much richer and deeper would it be than the anthropocentric narratives that have been set in place as histories of the world? Though long positioned as mute witnesses, the mere backdrop to human history, what might it tell us if it could speak? Within these frames we begin to sketch out the contemporary relationship between humans and the Wollemi and its politicisation, before moving into the speculative, to consider a reading of the Wollemi as attempting to be freed from anthropocentric hubris. 
A copse of ancient trees persists in an undisclosed location deep within the World Heritage-listed Wollemi National Park. Known also as Ganguddy by the local Wiradjuri, the park is a nationally recognised wilderness site within the Blue Mountains region of New South Wales. Contained within the Wollemi National Park is half a million hectares of old-growth forest, an environment reminiscent of Gondwana, and the time before geologic fracture. This thicket of ancient trees is one of the last wild populations of the Wollemi pine, a conifer from the Wollemia genus. What is remarkable about these trees is not only their scarcity, but that, until recently, the Wollemi was thought extinct and known only from fossil records. This dark green conifer, an evergreen that grows upwards of 30 metres in height, is a plant with a history that stretches back almost 200 million years, far eclipsing the human frame by a staggering amount. Despite the presence of the Wollemi within the fossil record, its story goes back only some 30 years, to the human 'discovery' of it. In rewriting the history of this plant, the human narrative ignores the enduring presence of the Wollemi. The Wollemi has witnessed the entire history of so-called Australia, from the arrival of the earliest inhabitants from the north, through to the invasion unleashed by arrivals from the South, but also the development of the landscape-innumerable seasons, unimpeded growth, and now, devastation.

The 'miraculous' rediscovery of this living fossil, the last remnant of the Wollemia genus, occurred as a team of abseilers explored the Greater Blue Mountains World Heritage Area. Their movement through the canyons and gullies of this remote wilderness revealed a small, untouched enclave in which these trees had been able to survive. This lack of human contact is given as one of the reasons why specific trees within this enclave are estimated to be over 1000 years in age (Wong, 2019). Whilst this isolation has aided the species' survival, it has also limited the Wollemi in some ways: initial genetic studies of these ancient conifers originally revealed no genetic diversity in the small wild population that was spread across four close sites-an 'evolutionary bottleneck' (Greenfield, et al. 2016; Peakall, et al. 2003). More recent studies, however, demonstrate small genetic variations between specimens, but, given the Wollemi once covered a vast area of the Gondwanan supercontinent, these similarities in genetic material demonstrate that for extended periods the tree has existed in relative seclusion (Greenfield, et al. 2016). The continued survival of the Wollemi is phenomenal in a time when plant growth has been reduced by half from the beginning of human civilisation (Bar-On, Phillips and Milo, 2019). This survival is set to become even more perilous, as the ongoing environmental degradation that results from climate change continues to present a threat to the Wollemi's existence (see Zimmer et al. 2014).

The ghostly figure of the Wollemi is further embedded through the manner in which the tree is described; a pine dinosaur (Anderson 1994), a lonesome pine (Anderson 1995, 1997; Jamieson 2005), a living fossil (Woodford 2002) and a dinosaur tree (Woodford 2005). The names acknowledge the prehistoric nature of the Wollemi, but the rarity hinted at in these names is reinforced by the deliberate absence of the conifer in a public sense. As a conservation measure, the exact location of the Wollemi grove has been kept a closely guarded secret. This is to preserve not only the trees themselves, but the fragile, symbiotic ecosystem in which they have thrived for 
millennia. Initial plans to protect the Wollemi grove noted the introduction of pathogens and weeds by visitors as threats to its survival, and in 2005, this threat became manifest when members of the wild population were found to be infected with Phytophthora cinnamomi, a harmful fungus introduced by unauthorised visitors (Salleh 2005). The safety and security of the Wollemi has come under pressure more recently, as their habitat was gravely threatened during the Black Summer bushfires of 2019/2020. As these fires razed large sections of Eastern Australia, including $81 \%$ of the World Heritage-listed Greater Blue Mountains Area and 54\% of the NSW components of the Gondwana Rainforests, the Wollemi sheltered; shielded from human interaction through secrecy, but unable to be protected from the increasingly disastrous impacts of anthropogenic climate change (Australian Disaster Resilience Knowledge Hub 2020). The risk of extinction posed to the Wollemi through these fires was so great that a team of firefighters were deployed by helicopter into their remote habitat as a matter of critical importance. Although some specimens were charred by the advance of the Gospers Mountain firefront, this grove of dinosaur trees is predicted to survive, at least until the next climactic challenge (Morton 2020).

Against this backdrop of extinction, absence and rediscovery, what could the thick and bubbled bark of this living fossil mean as a message? What might an artfully arranged spray of Wollemi within a bouquet symbolise? Mobilised within this hypothetical bouquet, the casual gifting of an endangered posy reinforces the anthropocentrism which has characterised human-plant relationships. However, whilst this image of the Wollemi as bouquet is mobilised here rhetorically, the gifting of entire specimens occurs within a geopolitical context, and in this frame, is heavily laden with significance. A sprig of Wollemi might signify a miracle, absence or rediscovery; something that in some way acknowledges time beyond human frames. The name 'Wollemi' itself carries significance, coming from the Aboriginal word 'wollumii,' meaning 'watch your step' or 'look around you' (Jones, et al. 1995); a name which speaks to the chance discovery of the plant, but further echoes an attentiveness to the looking that our plant blindness often obscures. This language, however, of ancientness, discovery and isolation, is an anthropocentric one, ascribed to the plant through human relationships. Within the Australian context of colonisation and dispossession, this feels amplified, and significantly more fraught. Since Invasion, this colonial power has controlled and shaped the landscape and vegetal ecologies of the country, radically altering and decimating human and more-than-human lives. Indeed, as Deborah Bird Rose, drawing from the work of Val Plumwood, writes, '[...] the legacy of colonisation in Australia "includes both genocide and ecocide"' $(2004,35)$.

With the movement of people through colonisation comes the movement of plants; as presence, through introduction to a non-native habitat, or absence, through felling and land clearing. This movement, particularly in the context of the invasion of so-called Australia, saw the projection of European taxonomic categorisations upon the land. With these categorisations came value judgements, which at the first instance falsely designated the land as terra nullius, but with the spread of the colonial population further into the country came perceptions of the land as wild, untamed and needing improvement (Instone and Taylor 2016, 135). From the entrance of the Endeavour into Ka-may, the lands and waters of the Gadigal people of the Eora Nation, these perceptions and categorisations unfolded. This location would come to be named 'Botany Bay,' in 
response to the vast quantities of plant specimens collected by the ship's botanists, Joseph Banks and Daniel Solander. Banks and Solander approached the vegetal ecologies of the continent 'as Linnaean botanists in a new land, its places and plants unnamed by any other; as if they were in a veritable terra nullius' (Buchan 2020). The importance of the Linnaean system within the framework of colonialism cannot be understated; systematising the study of nature through a new method of ordering and a new naming procedure fueled the racial speculation that became intertwined with colonialism and the varying strands of Enlightenment thinking. It is also important to note, within the context of this paper, that many of Linnaeus' writings and lectures were 'devoted to instructing others on "how to read Nature as any other Book"' (Baber 2016, 672). We can therefore interpret Linnaean taxonomy itself as a language of flowers, albeit one free from sentiment.

The perceived 'mastery' of nature, including the vegetal world, constituted an 'integral element of colonial power' and enabled the continued subjugation of the more-than-human (Baber 2016, 660661). Within the Australian context, an integral part of post-Invasion development was the clearing of land so as to establish pastoral properties and settlements. The sense of alienation experienced by the early colonists have been recorded at great length; the oft-quoted 'strange scribblings of nature learning how to write' (Clarke 1893, v), a nature that was 'out of kilter, 'widely considered to be metonymic of an attendant spiritual dis/ease' because it differed from the familiar natural environments of Europe (Turcotte 1998, 10). Edward Wilson, founder of the Zoological Society of Victoria, remarked of Australia that he had 'no idea of living in a half-furnished country,' exposing deep ignorance and indifference to a landscape which differed widely from the pastoral British countryside $(1857,86)$. The colony was seen as 'sadly deficient in useful and attractive creatures,' which led to the importation of European species in order to 'rectify' perceived absences in the landscape (Gillbank 2007, 69).

One such organisation tasked with this introduction of plants and animals of use and pleasure was the Acclimatisation Society of Victoria. As Gillbank explains, the ASV was 'an organisation truly of its time and sought to complete the work which Nature had apparently left incomplete in Australia (2007, 73-74). It is worth making abundantly clear here, through a helpful quote from Gillbank, how intertwined this project was with that of the colonial government. Speaking to a congregated ASV in 1862, Professor Frederick McCoy stated:

\footnotetext{
If Australia had been colonised by any of the lazy nations of the earth, this nakedness of the land would have been indeed an oppressive misfortune, but Englishmen love a good piece of voluntary hard work, and you will all, I am sure, rejoice with me that this great piece of nature's work has been left to us to do. (cited in Gillbank 2007, 74)
}

Indeed, the task that McCoy perceived as having been left to the industrious British is an ecological component to the broader 'civilising mission' the colonial society laboured under. As Lazarev helpfully outlines, the Enlightenment in Australia 'was predominately materialistic, agrarian and centred on the reclamation of what was regarded as wastelands at the expense of the dispossessed and excluded Indigenous people' $(2018,7)$. More broadly, however, this civilising mission was the belief, rooted in stadial theory, that it was the task of more 'advanced' societies to 
facilitate the modernisation of those seen as being less developed. This had devastating impacts upon Indigenous Australian peoples, but also the more-than-human world. Whilst the Linnaean system of taxonomy and naming may have created a language of flowers, and the romantic language of flowers overlain them with human sentiment and significance, colonial attempts to 'rectify' served to erase the already present, through removal or through the introduction of species that have come to be considered as pests. Notable cases include Echium plantagineum (Paterson's curse), Mimosa pigra and two subspecies of Chrysanthemoides monilifera (Boneseed and Bitou bush), all of which were introduced during the 19th century as ornamental plants but are now considered dangerous weeds.

The colonial devastation wrought by Invasion enacted genocidal erasure and willful destruction of Indigenous knowledges, landscapes and peoples as it spread across the Australian landscape. This devastation continues as the reverberations of colonisation persist, deeply felt yet willfully ignored within those structures that emerge from colonial power. Meaningful engagement with legacies of Invasion would necessarily involve recognition of Indigenous sovereignty, but with this, more-thanhuman agency and care for Country, as understood within Indigenous cosmologies. Indeed, Kenelm Burridge, as quoted by Rose, acknowledges Australian Aboriginal life as 'perhaps the most complicated representative of human life,' in recognition of notions of agentic and lively Country $(2000,25)$. New Materialist and agentic recognition of the liveliness of matter, and the coconstitutive nature of the more-than-human, 'spin[s] itself on the backs of non-European thinkers,' and is deeply indebted to 'their millennia of engagement with sentient environment, with cosmologies that enmesh people into complex relationships between themselves and all relations, and with climates and atmospheres as important points of organization and action' (Todd 2016, 67). Despite the Wollemi's seclusion and endangerment, hidden in secret on the lands of the Wiradjuri, Dharug, Wanaruah and Darkinjung people, we recognise that it nevertheless is part of active, continuing and very much alive Country. Although there is no homogenous Aboriginal conception of 'Country,' relationship to Country can be positioned, in the words of Noonuccal scholar Karen Lillian Martin, as 'relatedness,' emerging from rituals and ceremonies, but too, fishing, camping, talking about or walking on Country (Martin 2008, 80). Within the frame of Indigenous cosmologies, Country here speaks to the liveliness and co-constitutive nature of all things as acknowledged within the New Materialist frame.

Since Invasion, vegetal ecologies have been wielded by the colonial administration and the Australian government in turn. With the Wollemi's discovery, it too has become mobilised within this web and ascribed with anthropogenic significance. The messaging ascribed to the Wollemi through a particular form of political shorthand has seen the tree spread far from its isolated habitat, through the intervention of the human hand. Cuttings from the Wollemi have enabled the establishment of ex-situ populations in the Royal Botanic Gardens at Mount Annan in Sydney and botanic gardens overseas but have also increased the commercial availability of the Wollemi across Australia and internationally. But further to this, the Wollemi has moved beyond the confines of its historic home and has been engaged in diplomatic service by the Australian government. These movements bring the Wollemi into an international political sphere, gifted to embassies in Taiwan, Austria, New Caledonia, and Brazil (Wollemi Pine 2006). In 2004, the symbolism of the Wollemi was 
mobilised with the gift of the plant to the Vienna Botanic Gardens, described as representing 'the strong and enduring friendship Australia enjoys with the people of Austria,' drawing a comparison between the long history of the plant itself and the political desires of the Australian government (Wollemi Pine 2004). More recently, in 2015, then-Prime Minister Tony Abbott gifted a Wollemi seedling to Singaporean Prime Minister, Lee Hsien Loong, to symbolise relations between the two countries-'one that is precious, one that is evergreen, fresh and regularly blooming' (Liang 2005).

This deployment of the Wollemi as a diplomatic symbol reads into the tree a distinct 'Australianness.' The irony of this is clear, upon recognition that the perceived extinction of the Wollemi occurred millennia before 'Australia' was even a glimmer in the eye of the Empire. Further, the precarity of the Wollemi's contemporary existence means that it is mobilised as an international symbol of a population who have never been exposed to it amidst its natural setting. It is hard to miss also, as previously considered, the value ascribed to the Wollemi in light of its near extinction. In many ways, this gifting of the Wollemi is striking when contrasted with actions undertaken by the Australian Government which serve to imperil the more-than-human. Through performing this act of gifting, the problematic anthropogenesis we read into existing structures of power is reinforced. This reinforcement serves to further politicise the Wollemi, and, at the same time, reasserts the casual disregard of the Australian Government in relation to environmental concerns. In co-opting the Wollemi for deployment within the diplomatic frame, the tree is politicised within global frames, but more deeply within those of the local.

In terms of an arboreal vernacular, the Wollemi, as symbol and gesture becomes part of the language of the coloniser as it sweeps across the landscape; a governmental tool that is wielded in the attempt to further legitimise itself. The ancient Wollemi is forced to perform within these narrow and problematic frames, limiting its speech to a state-sanctioned script-one in which the colonial act is reperformed endlessly between dignitaries, moving Invasion beyond the single event to stretch across time. This occurs against the backdrop of climate change and collapse (itself deeply entangled in colonial histories) placing the vegetal, especially the precarious Wollemi, at further risk of extinction. While the Wollemi has become implicated within the legacies of colonialism through being utilised in this manner, this still serves to obscure the interimplication of ourselves and the vegetal world. This form of 'botanical imperialism' manifests as problematic cultivation, the 'appropriation, control and economic use' of the landscape by colonial powers in an attempt to figure the environment in an idealized form; one reminiscent of a 'civilized' (read: European) landscape. The political and vegetal are here deeply entwined with place and presence; a native plant, engaged in a complex relationship with occupation and invasion.

\section{Listening to Agentic Plants}

Like tendrils entwining, complex human-plant relationships can be attuned to through the recognition of the more-than-human in relation to colonisation and control. As we consider the capacity of communication through the vegetal, we posit that the agentic nature of the Wollemi has become complicated by the manner in which this plant is 'caught up [...] in specific relations of knowledge, power, colonialism' and biopolitics (Sandilands 2016, 227). Laden in this manner, the 
Wollemi accrues significance as a symbol within the language of the coloniser and through being mobilised and weaponised as symbol.

As previously canvassed, the Wollemi is gifted under the guise of representing a cultivated, colonial 'Australian-ness' and a desire to ensconce this shallow conception of nationhood within broader political spheres. Mobilised to further this facile conceptionof sovereignty, the casual gifting of the tree seems fitting. Removed from the earth, it becomes a political tool to be wielded. Ensconcement within these frames of international diplomacy and transit belies the deep roots of the Wollemi, which can be attuned to beyond this colonial frame, as part of a unique, persistent ecology. If the Wollemi must be mobilised within the context of sovereignty, we posit that it would instead speak to enduring and persistent conceptions of Country.

It is only through the shallow manipulation of the Wollemi within diplomatic frames that we can infer a deeper resonance of the conifer within Indigenous cosmologies. In light of this deployment, and in the relative absence of a durational cultural significance of the Wollemi, it becomes necessary to attempt to situate this plant within the landscape of our contemporary context. Again, we reiterate that this is reliant upon a willed reading of the Wollemi, but one oriented towards constructive and ethical ecological ends. We find ourselves keenly attuned to the spectre of extinction that seems to lurk, unseen, within every landscape. Anthropogenic climate change brings consistent temperature increases and long periods of drought, and subsequent longer and more catastrophic bushfire seasons. Increasingly devastating, they put innumerable species at risk, including the vegetal. Apprehending the Wollemi within this frame, we recall readily the existential precipice it faced during the 2019/20 bushfire season-facing extinction mere decades after its rediscovery. The continued existence of the Wollemi in light of this can enable its ready positioning within our current cultural moment as a symbol of ecological hope. This relates both to the survival of the Wollemi itself but can also be apprehended as speaking to a relative shift in attitudes towards the more-than-human. It is hard not to ascribe an apprehension of value in the morethan-human, in light of the response undertaken by authorities to the Wollemi's brush with second extinction.

It may be that, by acknowledging our critical reliance upon the vegetal world, plant histories and their wider cultural contexts, 'we might rewrite plants as key actors with agential capabilities, helping to shape history and culture' (Crawford 2017, 203). In treating the Wollemi as an agentic being, we question what we might glean if we attune to its vegetal language. Here, we endorse the Latourian perspective, wherein he acknowledges that he does not 'claim that things speak "on their own," since no beings, not even humans, speak on their own, but always through something or someone else' (Latour 2004, 69). In the case of this conifer, we look to its unique persistence and endurance for signs of what it might be able to impart upon us, in lieu of traditional human communicative methods, such as speech. Latour identifies the need for a speech prosthesis as a means of communicating the more-that-human to the human and aiding the more-than-human to 'speak for itself' (67). We suggest that it becomes possible for the human to attend to the vegetal in a Latourian prosthesis-like manner, via an attunement to the plant's flourishing or withering and in recognition of its agency. This means, however, that in lieu of an established, sensible method 
of communicating across human/plant relationships, our gleaning of 'lessons' from the vegetal will be necessarily underlain by an assumption that remains, however unfortunately, anthropocentric.

In the context of the Wollemi, and in acknowledgement that this is a willed reading of the plant, it becomes possible to think of the continued survival of this prehistoric conifer in such an isolated location as a willful act on the part of the Wollemi. Whilst we fully recognise how fantastic this may seem, the leap of faith implicit in this ascription of will to plants may be a necessary step to take in our attempts to attune to a mode of vegetal thinking. The Wollemi presents the opportunity for the attuned human to learn of endurance amidst ecological crisis. It might be that by turning toward the Wollemi, we might learn to lessen our place in the world. But furthermore, as a Lazarus taxon and a critically endangered species, the real risk of extinction for the more-than-human, particularly within the context of our rapidly changing natural world, becomes increasingly clear. The durational presence of this species across millennia of human history throws into sharp relief the rapid rate at which humanity has changed and the mutability of borders, governments and nations.

We have endeavoured to demonstrate through this text the manner in which the vegetal is readily ensnared within complex entanglements of human and vegetal biopolitics. In exploring the case of the Wollemi, we have considered how the imposition of symbolic meaning upon vegetal beings has the capacity to obscure, if not outwardly deny, their agentic nature. We have too sought to identify that this speaking for the vegetal invites their weaponisation towards distinct political ends. In recognition of increasing globalisation and connectivity, we think too toward the role of the vegetal within this landscape of relations. As we experience the broad-ranging consequences of anthropogenic climate change emerging from durational environmental mismanagement, the interimplicative relationships between the human and more-than-human become clear, in the navigation of contemporary precarity. Through practices of attention, attunement and listening, in recognition of plant agency, the communicative capacities of the vegetal can be gleaned from beyond the cacophony of human voices and the symbolism foisted upon them. The reconfiguration of human/plant relationships towards ethical interimplication is increasingly critical, so as to ensure the continued dynamism of our shared world.

Notes

\footnotetext{
${ }^{1}$ Plant blindness as a concept emerged as a metaphorical way of speaking to the perceptual barrier in recognising the presence and richness of plants, with Wandersee and Schussler 'diagnosing' those with plant blindness as 'exhibit[ing] symptoms such as the following: (a) thinking that plants are merely the backdrop for animal life; (b) failing to see, notice or focus attention on plants in one's daily life; (c) misunderstanding what plants need to stay alive; (d) overlooking the importance of plants to one's daily affairs.' (Wandersee \& Schussler 1999, 82). Contemporary critique of the concept of plant blindness, however, acknowledges the possibility of ableist overtones (see Mackenzie et al. 2019,139).

2 We read the presence of a vital New Materialism within the work of both Marder and Tsing. Within their respective theoretical frameworks, and in relation to their approaches to the vegetal, notions of agency and vibrancy are present. For Marder, decentering the human in the frame of a vegetal philosophy is central to an apprehension of 'plant-thinking,' and apprehension of the 'non-conscious intentionality of plants' (2013b, 124). In the work of Tsing, this agentic recognition illuminates 'the romance connecting people, plants, and places,' a connectivity within which plants are agents $(2012,145)$.
} 


\section{Works Cited}

Anderson, lan. 1994. "Pine 'Dinosaur Lurks in Gorge."' New Scientist 1957, 24 December. Accessed 15 November 2020. https://www.newscientist.com/article/mg14419570-500-pine-dinosaur-lurks-in-gorge/

1995. "Lonesome pines at risk from collectors." New Scientist 1967, 4 March. Accessed 10 November, 2020. https://www.newscientist.com/article/mg14519670-400-Ionesome-pines-at-risk-from-collectors/

Australian Institute for Disaster Resilience. 2020. "Bushfires - Black Summer." Australian Disaster Resilience Knowledge Hub. Accessed 3 December 2020. https://knowledge.aidr.org.au/resources/black-summerbushfires-vic-2019-20/

Baber, Zaheer. 2016. "The Plants of Empire: Botanic Gardens, Colonial Power and Botanical Knowledge." Journal of Contemporary Asia 46 (4): 659-697. https://doi.org/10.1080/00472336.2016.1185796

Bar-On, Yinon M., Rob Phillips, and Ron Milo. 2018. "The biomass distribution on Earth." Proceedings of the National Academy of Sciences 115 (25): 6506-6511. https://doi.org/10.1073/pnas.1711842115

Barad, Karen. 2012. "Matter feels, converses, suffers, desires, yearns and remembers." In New Materialism: Interviews \& Cartographies, edited by Iris van der Tuin and Rick Dolphijn, 48-70. Ann Arbor: MPublishing/Open Humanities Press.

Bawaka Country, Sarah Wright, Sandie Suchet-Pearson, Kate Lloyd, Laklak Burarrwanga, Ritjilili Ganambarr, Merrkiyawuy Ganambarr-Stubbs, Banbapuy Ganambarr, and Djawundil Maymuru. 2015. "Working with and learning from Country: decentring human author-ity." Cultural Geographies 22 (2): 269-283. https://doi.org/10.1177/1474474014539248

Bennett, Jane. 2010. Vibrant Matter: A political ecology of things. Durham, NC: Duke University Press. https://doi.org/10.2307/j.ctv111jh6w

Blok, Anders. 2017. "Deep in the Maze: Urban Nature and Repetitions of the Not-Quite-Similar." In Moving Plants, edited by Line Marie Thorsen, 103-120. Næstved: Rønnebæksholm.

Bousfield, Dan. 2020. "Settler colonialism in vegetal worlds: exploring progress and resilience at the margins of the Anthropocene." Settler Colonial Studies 10 (1): 15-33. https://doi.org/10.1080/2201473X.2019.1604297

Braidotti, Rosi. 2019. "A Theoretical Framework for the Critical Posthumanities." Theory, Culture \& Society 36: $31-$ 61. https://doi.org/10.1177/0263276418771486

Buchan, Bruce. 2020. "Botany and the colonisation of Australia in 1770." The Conversation, April 29. Accessed 3 November 2020. https://theconversation.com/botany-and-the-colonisation-of-australia-in-1770-128469

Chamowitz, Daniel. 2012. What a Plant Knows: A Field Guide to the Senses of Your Garden-and beyond. Oxford: Farrar, Straus \& Giroux.

Clarke, Marcus. 1893. "Preface." Poems of the Late Adam Lindsay Gordon. Melbourne: Massina.

Coole, Diana, and Samantha Frost, eds. 2010. New Materialisms: Ontology, Agency and Politics. Durham, NC: Duke University Press. https://doi.org/10.2307/j.ctv11cw2wk

Crawford, Emily. 2007. "Plant/Human Borderland Jamming." Transformations 30: 203-218.

Doolittle, William E. 2004. "Gardens Are Us, We Are Nature: Transcending Antiquity and Modernity." Geographical Review 94 (3): 391-404. https://doi.org/10.1111/j.1931-0846.2004.tb00179.x

Farley, Kathleen A. 2007. "Grasslands to tree plantations: forest transition in the Andes of Ecuador." Annals of the Association of American Geographers 97 (4): 755-771. https://doi.org/10.1111/j.1467-8306.2007.00581.x

Gamble, Christopher N., Joshua S. Hanan and Thomas Nail. 2019. "What is New Materialism." Angelaki 24 (6): $111-$ 134. https://doi.org/10.1080/0969725X.2019.1684704

Gibson, Prudence. 2018. The Plant Contract: Art's Return to Vegetal Life. Leiden: Brill. https://doi.org/10.1163/9789004360549 
Gillbank, Linden. 2007. "Of Weeds and Other Introduced Species: Ferdinand Mueller and Plant and Animal Acclimatisation in Colonial Victoria." The Victorian Naturalist 124 (2): 69-78.

Greenfield, Abigail, Hannah McPherson, Tony Auld, Sven Delaney, Catherine A. Offord, Marlien van der Merwe, JiaYee S. Yap and Maurizio Rossetto. 2016. "Whole-Chloroplast Analysis as an Approach for Fine-Tuning the Preservation of a Highly Charismatic but Critically Endangered Species, Wollemia nobilis (Araucariaceae)." Australian Journal of Botany 64: 654-658. https://doi.org/10.1071/BT16105

Hall, Matthew. 2011. Plants As Persons. Albany: SUNY Press.

Head, Lesley, and Jennifer Atchison. 2009. "Cultural Ecology: Emerging Human-Plant Geographies." Progress in Human Geography 33 (2): 236-245. https://doi.org/10.1177/0309132508094075

Ingold, Tim. 2011. Essays on Movement, Knowledge and Description. London and New York: Routledge.

Instone, Lesley, and Affrica Taylor. 2016. "Thinking About Inheritance Through the Figure of the Anthropocene, from the Antipodes and in the Presence of Others." Environmental Humanities 7 (1): 133-150. https://doi.org/10.1215/22011919-3616371

Jones, Wyn, Ken Hill, and Jan Allen. 1995. "Wollemia Nobilis, a New Living Australian Genus and Species in the Araucariaceae." Telopea 7 (2-3): 173-176. https://doi.org/10.7751/telopea19953014

Jones, Martin. 2007. Feast: Why Humans Share Food. Oxford: Oxford University Press.

Jones, Owain, and Paul Cloke. 2002. Tree Cultures: The Place of Trees and Trees in Their Place. London and New York: Taylor and Francis.

Kirksey, Scott, Craig Schuetze, and Stefan Helmreich. 2014. "Tactics of Multispecies Ethnography." In The Multispecies Salon, edited by Eben Kirksey, 1-24. Durham, NC: Duke University Press. https://doi.org/10.1215/9780822376989-001

Kirksey, Scott, and Stefan Helmreich. 2010. "The Emergence of Multispecies Ethnography." Cultural Anthropology 25 (4): 545-576. https://doi.org/10.1111/j.1548-1360.2010.01069.x

Kranz, Isabel. 2017. "The Language Of Flowers In Popular Culture And Botany." In The Language Of Plants: Science, Philosophy, Literature, edited by Monica Gagliano, John C. Ryan, and Patrícia Vieira, 193-214. Minneapolis: University of Minnesota Press.

Latour, Bruno. 1993. The Pasteurization Of France. Cambridge, MA: Harvard University Press.

2004. Politics of Nature. Cambridge, MA: Harvard University Press.

Lazarev, Ilya. 2018. The Enlightenment, philanthropy and the idea of social progress in early Australia: Creating a happier race? New York: Routledge. https://doi.org/10.4324/9780429445439

Liang, Lim Yan. 2015. "Gift of Trees to Symbolise Evergreen Relations." The Straits Times, 30 June. Accessed November 15, 2020. https://www.straitstimes.com/singapore/gift-of-trees-to-symbolise-evergreenrelations

Mabey, Richard. 2016. The Cabaret of Plants: Forty Thousand Years of Plant Life and the Human Imagination. New York: WW Norton \& Company.

Mamdani, Mahmood. 2012. Define and Rule: Native as Political Identity. Cambridge, MA: Harvard University Press. https://doi.org/10.4159/harvard.9780674067356

Marder, Michael. 2013a. Plant-thinking: A Philosophy of Vegetal Life. New York: Columbia University Press. 2013b. "What is Plant Thinking?" Klesis: Revue Philosophique 25: 124-143.

2018. "Interview with Michael Marder." In Covert Plants: Vegetal Consciousness and Agency in the Anthropocentric World, edited by Prudence Gibson and Baylee Brits, 25-36. Santa Barbara: Punctum Books.

Martin, Karen Lillian. 2008. Please Knock Before You Enter: Aboriginal regulation of Outsiders and the implications for researchers. Brisbane: Post Press. 
McCoy, Frederick. 1862. "Acclimatisation, its Nature and Applicability to Victoria." The First Annual Report of the Acclimatisation Society of Victoria. Melbourne: Acclimatisation Society of Victoria.

McDonough MacKenzie, Caitlin, Sara Kuebbing, Rebecca S. Barak, Molly Bletz, Joan Dudney, Bonnie M. McGill, Mallika A. Nocco, Talia Young, and Rebecca K. Tonietto. 2019. 'We do not want to "cure plant blindness" we want to grow plant love.' Plants, People, Planet 1 (3): 139-141. https://doi.org/10.1002/ppp3.10062

McGee, Peter A., Suzanne Bullock, and Brett A. Summerell. 1999. "Structure of Mycorrhizae of the Wollemi Pine (Wollemia nobilis) and Related Araucariaceae." Australian Journal of Botany 47: 85-95. https://doi.org/10.1071/BT97064

Morton, Adam. 2020. "Dinosaur trees': firefighters save endangered Wollemi pines from NSW bushfires." Guardian. 15 January. Accessed 12 November 2020. https://www.theguardian.com/australia-news/2020/jan/15/ dinosaur-trees-firefighters-save-endangered-wollemi-pines-from-nsw-bushfires

Myers, Natasha. 2014. "Sensing Botanical Sensoria: A Kriya for Cultivating Your Inner Plant." Centre for Imaginative Ethnography. Accessed 13 October 2020. https://imaginative-ethnography.com/imaginings/affect/ sensing-botanical-sensoria/

2016. "Photosynthesis." Theorizing the Contemporary, Fieldsights. Accessed 13 October 2020. https://culanth.org/fieldsights/photosynthesis

___. 2017. "Photosynthetic Mattering: Rooting into the Planthroposcene." In Moving Plants, edited by Line Marie Thorsen, 123-130. Næstved: Rønnebæksholm.

Nealon, Jeffrey T. 2015. Plant Theory: Biopower and Vegetable Life. Stanford: Stanford University Press. https://doi.org/10.1515/9780804796781

New South Wales Department of Environment and Conservation. 2006. Wollemi Pine (Wollemia nobilis) Recovery Plan. Hurstville: NSW Department of Environment and Conservation.

New South Wales Department of Planning, Industry and Environment. 2020. “Understanding the Effects of the 1920 Fires." Recovering from the 2019-20 Fires. Accessed 12 November 2020. https://www.environment.nsw.gov.au/topics/parks-reserves-and-protected-areas/fire/park-recoveryand-rehabilitation/recovering-from-2019-20-fires/understanding-the-impact-of-the-2019-20-fires

Pangesti, Nurmi, Ana Pineda, Corné M J Pieterse, Marcel Dicke, and Joop J A van Loon. 2013. "Two-way plant mediated interactions between root-associated microbes and insects: from ecology to mechanisms." Frontiers in Plant Science 4: article 414. https://doi.org/10.3389/fpls.2013.00414

Peakall, Rod, Daniel Ebert, Leon J Scott, Patricia F Meagher, and Cathy A Offord. 2003. "Comparative genetic study confirms exceptionally low genetic variation in the ancient and endangered relictual conifer, Wollemia nobilis (Araucariaceae)." Molecular Ecology 12 (9): 2331-43.

https://doi.org/10.1046/j.1365-294X.2003.01926.X

Pitt, Hannah. 2016. An Apprenticeship in Plant Thinking. In Participatory Research in More-than-Human Worlds, edited by Michelle Bastian, Owain Jones, Niamh Moore, and Emma Roe, 106-120. London and New York: Routledge.

Rose, Deborah Bird. 2000. Dingo Makes Us Human: Life and Land in an Australian Aboriginal Culture. Cambridge: Cambridge University Press.

2004. Reports From a Wild Country: Ethics for Decolonisation. Sydney: UNSW Press.

Sarah, P., and M. Zonana. 2015. "Livestock Redistribute Runoff and Sediments in Semi-Arid Rangeland Areas." Solid Earth 6: 1-11. https://doi.org/10.5194/se-6-433-2015

Salleh, Anna. 2005. "Wollemi Pine Infected by Fungus." ABC Science, 4 November. Accessed 1 December 2020. http://www.abc.net.au/science/articles/2005/11/04/1497961.htm

Sandilands, Catriona. 2016. "Floral Sensations: Plant Biopolitics." The Oxford Handbook of Environmental Political Theory. Oxford: Oxford University Press. https://doi.org/10.1093/oxfordhb/9780199685271.013.33 
Shakespeare, William. 2005. Four Tragedies: Hamlet, Othello, King Lear, Macbeth. Edited by David Bevington and David Scott Kastan. New York: Bantam Classics.

Soler, Roxina, Jeffrey A Harvey, T Martijn Bezemer and Josef F Stuefer. 2008. "Plants as green phones: Novel insights into plant-mediated communication between below- and above-ground insects." Plant Signaling \& Behavior 3 (8): 519-520. https://doi.org/10.4161/psb.3.8.6338

Thorsen, Line Marie. 2017. "Introduction: Moving Plants." In Moving Plants, edited by Line Marie Thorsen, 11-15. Næstved: Rønnebæksholm.

Todd, Zoe. 2016. "An Indigenous Feminist's Take on the Ontological Turn: 'Ontology' Is Just Another Word for Colonialism." Journal of Historical Sociology 29 (1): 4-22. https://doi.org/10.1111/johs.12124

Trewavas, Anthony. 2002. "Plant Intelligence: Mindless Mastery." Nature 415 (6874): 841. https://doi.org/10.1038/415841a

___. 2003. "Aspects of Plant Intelligence." Annals of Botany 92 (1): 1-20. https://doi.org/10.1093/aob/mcg101

Tsing, Anna Lowenhaupt. 2015. The Mushroom at the End of the World: On the Possibility of Life in Capitalist Ruins. Princeton: Princeton University Press. https://doi.org/10.2307/j.ctvc77bcc

___. 2017. "Moving plants: appreciating Koichi Watanabe." In Moving Plants, edited by Line Marie Thorsen, 2126. Næstved: Rønnebæksholm.

Turcotte, Gerry. 1998. "Australian Gothic." In The Handbook to Gothic Literature, edited by M. Mulvey Roberts, $10-$ 19. Basingstoke: Macmillan Press.

Wandersee, James H., and Elisabeth E. Schussler. 1999. "Preventing Plant Blindness." The American Biology Teacher 61 (2): 82-86. https://doi.org/10.2307/4450624

Wild, Eva, Robin Golser, Peter Hille, Walter Kutschera, Alfred Priller, Stephan Puchegger, Werner Rom, Peter Steier, and Walter Vycudilik. 1997. "First 14C Results from Archaeological and Forensic Studies at the Vienna Environmental Research Accelerator." Radiocarbon 40: 273-281. https://doi.org/10.1017/S0033822200018142

Wilson, Edward. 1857. "On the Introduction of the British Songbird." Transactions of the Philosophical Institute of Victoria 2: 77-88.

Wollemi Pine. 2004. "Wollemi Watch Issue 6." Accessed 12 November 2020.

http://www.wollemipine.com/watch/issue_6.php

___. 2006. "Wollemi Watch Issue 12." Accessed 12 November 2020.

http://www.wollemipine.com/watch/issue_12.php

Woodford, James. 2002. The Wollemi Pine. Melbourne: Text Publishing.

___. 2005. "Prehistoric Miracle: Our Dinosaur Tree." Australian Geographic 80: 50-57.

Wong, Luke. 2019. "Dinosaur tree' Wollemi pines safe for now as Blue Mountains bushfires continue to burn." ABC News. 5 December. https://www.abc.net.au/news/2019-12-05/wollemi-pine-trees-national-park-firesblue-mountains/11763420

Zimmer, H., T. Auld, J. Benson, and P. Baker. 2014. "Recruitment bottlenecks in the rare Australian conifer Wollemia nobilis." Biodiversity and Conservation 23: 203-215. https://doi.org/10.1007/s10531-013-0593-2 


\section{Biographies}

Chantelle Mitchell and Jaxon Waterhouse are researchers and writers from so-called Australia, working across academic and contemporary arts settings through their research project Ecological Gyre Theory. Together, their work has appeared in un Magazine, e-flux, art+Australia, and Unlikely Journal, with other publication outcomes currently under peer review, and chapters for publications with Bloomsbury forthcoming in 2022. They have presented their work at conferences nationally and internationally, and exhibited their work in Australian artist run spaces. Most recently they have presented through Macquarie University, the international Temporal Belongings, STREAMS and Atmospheric Humanities conferences, and the Australian Centre for Contemporary Art for the Writing\&Concepts series-although COVID-19 has disrupted a number of further forthcoming engagements in Sweden, Norway, Greece and Finland. They have shown their work at Sawtooth ARI, Launceston (deluge, Jan - Feb 2020) and have taught their writing and practice focused curriculum 'Abyss Lessons' through Bus Projects in 2020. 2021 sees exhibitions at Spectrum Gallery (W.A.) The University of Melbourne (VIC), Sawtooth ARI (Tas) and FELTspace ARI (S.A.), alongside further practice based outcomes in 2022. They are currently guest editors for Issue 8 of Swamphen: a journal of cultural ecology.

Chantelle Mitchell lives on unceded Wurundjeri Country. She has written for Stilts Journal, Heart of Hearts Press, Plumwood Mountain, the Lifted Brow and Marrickville Pause, and presented performance lectures for ACCA, the Ian Potter Museum, Bus Projects and Free Association. Chantelle maintains a research-based practice with Jaxon Waterhouse, which has seen them present their work through Macquarie University, the Australian Centre for Contemporary Art, the international Temporal Belongings, STREAMS and Atmospheric Humanities conferences. Their written work has appeared in unMagazine, e-flux, art+Australia and Unlikely Journal, and they have presented numerous exhibitions in artist run spaces across Australia.

Jaxon Waterhouse is a writer, publisher, and artist living on unceded Ngarluma Country in regional Western Australia. He is the editor of Heart of Hearts Press, which has seen numerous publications and artist books between 2020 and 2021. In 2021, he presented the immersive digital artwork, Quest for the Night Parrot, alongside numerous exhibitions across Australia. Jaxon maintains a research based practice with Chantelle Mitchell which has seen them present their work at a number of national and international conferences. Their written work has appeared in unMagazine, e-flux, art+Australia and Unlikely Journal, and they have presented numerous exhibitions across Australia.

(c) 2021 Chantelle Mitchell and Jaxon Waterhouse

Except where otherwise noted, this work is licensed under a Creative Commons Attribution-

NonCommercial-ShareAlike 4.0 International License. 